\title{
The Effect of Using Hypermedia-Supported Individualized Education on the Level of Technical and Quantitative Performance in High Jump Event *Dr/ Shaimaa Mustafa Abdullah Ali
}

\section{Abstract:}

This research aims at writing a suggested educational program based on hypermediasupported individualized education style and identifying its effect on the level of technical and quantitative performance in high jump event for the second-year undergraduate students at the Faculty of Physical Education for Girls, Zagazig University. The researcher has conducted an empirical study on a sample of (48) second-year undergraduate students at the Faculty of Physical Education for Girls, Zagazig University. They were divided into two groups, an experimental group and a control group (command teaching style), of (24) students each.

The research tools included: intelligence test physical tests - assessment and measurement of the level of technical and quantitative performance in high jump - the suggested educational program based on hypermedia- supported individualized education.

The researcher has used the following statistical processes: arithmetic mean - standard deviation - median - skewness - simple correlation coefficient $\mathrm{T}$ test - rate of improvement $\%$.

Key results:

- Hypermedia-supported individualized education has more efficiency than command teaching style on the level of technical and quantitative performance in high jump.

\section{Recommendations:}

- The necessity of using hypermedia-supported individualized education in learning and mastering high jump skills for the second-year undergraduate students at the Faculty of Physical Education at Zagazig.

Introduction and problematic:

The individualized learning is a method of managing the educational process in a way that involves the learners in the educational tasks that suit their own needs and levels. It could be an

"Professor at the Department of Track and Field Events

Assiut Journal For Sport Science Arts 
approach that allows them to study the educational subject in accordance with their own abilities and rapidity of learning under the supervision of a teacher who assists them in solving the issues they encounter during their studies in order to achieve the educational objectives. The individualized learning is a modern trend in teaching styles which depends on the fact that most teachers commit a mistake by explaining the lessons in a manner that suits the intermediate-level learner, while such manner does not necessarily suit the abilities of low and high level learners, which implies that we should take the individualized learning into consideration.

Kevien Oliver (2000) and Emck \& Ferguson (2005) agree that individualized education (Keller Plan) is an educational system which is based on the division of the educational curriculum into a series of little modules (educational modules) to be handled separately. Each module contains determined educational objectives that the learners should know in order to identify what is expected from them and be able to focus on the key points of the curriculum. Such method excludes exams panic by allowing the learners to have a makeup exam in order to give them self-enhancement and make them feel happy and satisfied. Furthermore, in this educational system, students do not undergo punishment when they don't pass a certain module exam; however, mastering the educational course is indispensible, as the learners are obliged to achieve a certain level of mastery.

Hypermedia is one of the modern educational technologies. It's an educational plan that can be used in the linear transmission of information. It involves the learner's senses, sight and hearing, and provides interaction between the learner and a set of educational multimedia on which information have been stored in the form of written texts, animated and static shots, animations and static images, films, consistent colors, audio recordings, music, all of which can be easily and rapidly controlled in a way that allows the learner to make logical associations, which make it easier to pass, skip and move freely, in a non linear way, 
between the different parts of the information and to control the exchange of all or part of the information which has been stored and broken down into little parts by means of the computer in order to achieve the educational goals of the educational program in a competent and efficient manner.

High jump is an event which is characterized by its beautiful movement rhythm, its agility and flexibility. This can be figured out by both the competitor and the audience and demonstrates through the event's special techniques which passe through some specific motor stages (approach, take off, flight and landing).

By teaching the program of track and field events to the second-year students at the Faculty of Physical Education for Girls, Zagazig University, the researcher has noticed a decrease in the level of technical and quantitative performance of high jump among the second-year undergraduate students at the faculty. This may be due to the difficulty of teaching high jump events as it requires good motor co-ordination and perfect sequencing and combination of body movements during the performance, which requires lot of efforts during the teaching process, in addition to the use of command teaching style which depends on a single source of knowledge; verbal explanations followed by the representation of the model by the teacher, without any active participation from the student in the educational situation. In addition, some learners may not follow-up the explanations or find it difficult to understand what is required from them. Others may not be able to see the model clearly and accurately.

Hence has emerged the main idea of this research as a scientific attempt to identify the effect of using hypermediasupported individualized learning on the level of technical and quantitative performance in high jump for the second-year students at the Faculty of Physical Education for Girls, Zagazig University.

\section{Research goals:}

The research aims at putting a suggested educational program based on hypermediasupported individualized learning and identifying its 
impact on the level of technical and quantitative performance in high jump for the secondyear undergraduate students at the Faculty of Physical Education for Girls, Zagazig University.

\section{Research hypotheses:}

- There are statistically significant differences between the averages of the post and pre tests of the (low level - high level) experimental group in terms of the level of technical and quantitative performance in high jumping skill in favor of the post test.

- There are statistically significant differences between the post and pre tests of the (low level - high level) control group in terms of the level of technical and quantitative performance in high jumping skill in favor of the post test.

- There are statistically significant differences between the post tests of both the (low level - high level) experimental and the control groups in terms of the level of technical and quantitative performance in high jumping skill in favor of the experimental group.

Research procedures:

Methodology:
The researcher has conducted an empirical research using the experimental design of two groups: an experimental group and a control group, given that this method suits the nature of the research.

\section{Population and sample:}

By means of the purposive sampling, the researcher has chosen (63) second-year undergraduate students at the Faculty of Physical Education for Girls, Zagazig University from a total research population of (265) students for the academic year $2013 / 2014$ ), in the rate of $(23.77 \%)$.

(15) Students were excluded for the exploratory study, so the basic research sample would be (48) students divided into two groups: an experimental group and a control group of (24) students each.

\section{Division of the research's two groups:}

The students' results in the research's two groups were sorted in an ascending order in terms of their technical and quantitative performance in high jump. Afterwards, the individuals of the two groups, both the experimental and the control group, were divided 
into two levels (low level -

high level), as shown in table

Table (1)

Division of the individuals of the experimental and the control group in relation to the level of technical and quantitative performance in high jump

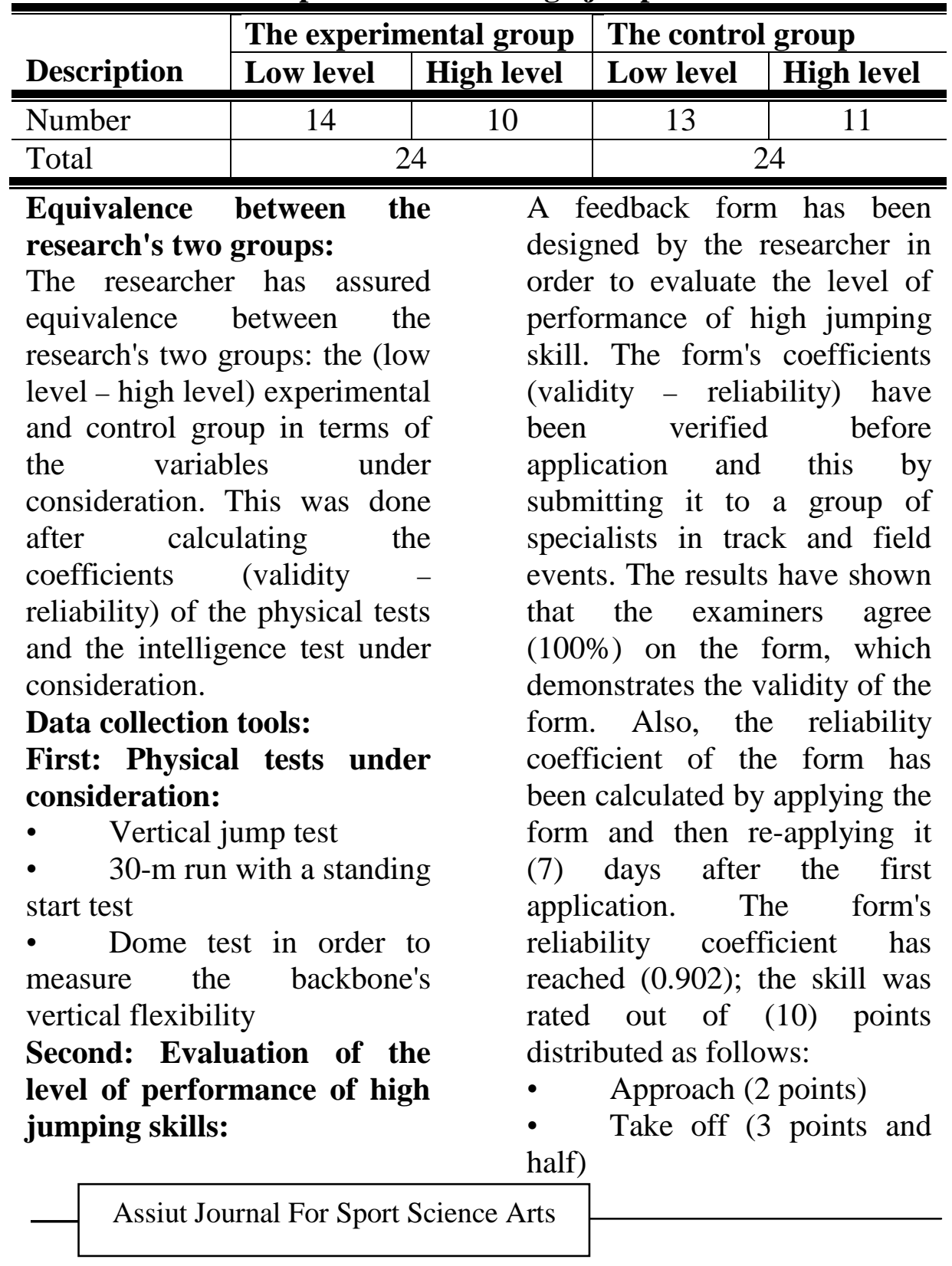


- $\quad$ Flight (3 points and half)

- $\quad$ Landing (one point)

The level of performance of high jump has been evaluated by (3) experienced examiners in teaching track and field events, each one of them gave a mark to the student, and afterwards we calculated the average of all three marks.

Third: Measuring the quantitative level in high jump

The researcher has measured the quantitative level in high jump in accordance with the rules of IAAF - International Association of Athletics Federations.

Fourth: Intelligence test / prepared by Mr. Essayed Mohamed Khairy (1989)

The suggested educational program based

hypermedia-supported individualized learning

The educational program's general objective:

- $\quad$ Learning and mastering high jumping skill for the second-year undergraduate students at the Faculty of Physical Education for Girls, Zagazig University (low level and high level experimental groups).

Basis for putting the educational program:
The researcher has put the suggested educational program in accordance with the following scientific basis:

- The program content's logical sequence shall be suitable for its objectives and for the properties of the research sample.

- The information of the educational program shall be given in a comprehensive, correlated and effective manner which involves all the learner's senses.

- The program content shall challenge the learners' abilities and potentials, all while respecting the individual differences and increasing their motivation to learn.

- $\quad$ The form and size of the animated photos, videos and cognitive text shall be adapted to the screen size.

- All graphics, photos and videos shall be displayed by computer besides the cognitive text.

- the researche has conducted some drilles (EX)

- 1-running : increase intensityof workout over time ,develope good sprint mechanicas ,moe sprint drills with high jump technique .

\section{Assiut Journal For Sport Science Arts}


- 2-approach : straight line rhythm approach 1"2"3...1"2"3...jump

,aapproach with bar lying on graund, foot strike and bady lean feel the preasure, focus on traneition into curve with cross over step.

- A(take off point ) : depends on speed of apprdach and strength of jumper, more marrour approaches create greater centripetal force and faster rotation about the bar

- $\mathrm{B}($ the curve) : imtiate curve on 6th step,left footed turn right slightly on 6th step, 6th step should a slight croes over to mid line of bady,feel preasureand run around the curve is should lower center of mass,puah through the turn.

- 3-(over the bar): standing back over, from ground on box, 4 or 6 step jump from a ranp, focus rotale right knee out, drive head and shoulders toward back side of the pit .

- The learner shall work on the computer, choose from the table of contents and navigate in the program by herself in accordance with the required educational level.

- The learner shall be able to determine the routing and path she has to follow, the amount of information she has to recall and control her rapidity of learning in the program.

- The program shall progress from easy to difficult in accordance with the level of each student.

- The program shall be diversified, comprehensive and simplified in order to cater to the students' motor needs.

\section{Determining the level of the educational software}

The process of choosing the content is one of the most difficult steps in building an educational software, this difficulty consists in choosing the facts, concepts and information specific to high jumping skills as well as selecting the videos, illustrations for the stages of performance of the skill under consideration, music tracks and other chosen educational materials and tools, organizing it in a specific pedagogical manner and identifying the trajectory in a way that contributes to the achievement of the educational program.

Stages of software
production:
- Preparing the
program's scenario in
its primary form:


The program's scenario has been prepared in light of the general desired objectives and the educational curriculum specific to high jumping skill. It was presented to a group of specialists in track and field events and teaching methods from the members of the teaching staff at the Faculties of Physical Education, and this in order to explore their opinions on the program's general objective, purposes, basics, contents, scientific accuracy, the software's presentation style and the program's applicability. The experts have highlighted the necessary modifications for the program to be effectively applicable.

\section{B- Preparing the final form of the program's scenario}

The researcher has undertaken the necessary modifications as pointed out by the experts. The program's scenario was resubmitted to the experts after modification. After the researcher had explored the experts' opinion, it was shown that they have $(90,00 \%)$ agreed on the scenario in its final form, and thus the software was ready to implement in its final form.

\section{Schedule of the suggested educational program:}

- The duration of the application experience will be (6) weeks.

- The duration of each lecture shall be (90) minutes which is the typical duration of practical lectures at the Faculty. (45) Minutes were dedicated for the implementation of the suggested educational program. The remaining time of the lecture (45) minutes was dedicated for teaching the remaining curriculum of track and field events for the secondyear undergraduate students at the Faculty.

- $\quad$ Number of modules: (2) modules per week.

- Number of modules: (12) modules in the educational program.

- The lecture's total time for the experimental group was divided as follows: (interaction with the educational software 10 min.), (physical warm-up 10 min), (practical application / trainings $25 \mathrm{~min}$.).

- The lecture's total time for the control group was divided as follows: (model and verbal explanations $10 \mathrm{~min}$.), (physical warm-up $10 \mathrm{~min}$.), (practical application / trainings $25 \mathrm{~min}$.). 
Pre tests:

Before calculating the pre tests, the researcher had taught two educational modules for the individuals of the basic research sample so that all the individuals of the sample could reach a specific level starting from which the researcher would be able to conduct the pre tests and this for the period from 25/02/2014 till 10/03/2014. Afterwards, the researcher conducted the pre tests for the (low level - high level) experimental and control groups in terms of their level of technical and quantitative performance in high jump for the period from 11/03/2014 till 12/03/2014.

\section{Implementation of the suggested educational} program The program's content was educational implemented by means of hypermedia-supported individualized education on the individuals of the (low level high level) experimental group for (6) continuous weeks, and this for the period from 12/03/2014 till 24/04/2014. Also, the traditional style was followed with the (low level high level) control group.

Post tests:

The researcher has calculated the post tests for the (low level - high level) experimental and control groups in terms of their level of technical and quantitative performance in high jump, for the period from 27/04/2014 till $29 / 04 / 2014$, following the same order and conditions of the pre tests.

Presentation and discussion of results:

First: Presentation and discussion of the results of the research's first hypothesis:

\section{Table (2)}

Indication of the differences between the pre and post tests of the (low level) experimental group in terms of the technical and quantitative performance in high jump $\mathrm{N}=14$

\begin{tabular}{c|c|c|c|c|c|c}
\hline \hline \multirow{2}{*}{$\begin{array}{c}\text { T } \\
\text { value }\end{array}$} & \multicolumn{2}{|c|}{ Post test } & \multicolumn{2}{c|}{ Pre test } & $\begin{array}{c}\text { Unit of } \\
\text { Measurement }\end{array}$ & Variables \\
\hline \hline $11.37^{*}$ & 0.51 & 6.48 & 0.55 & 1.00 & Mark & $\begin{array}{l}\text { Level of } \\
\text { technical } \\
\text { performance } \\
\text { in high } \\
\text { jump }\end{array}$ \\
\hline $18.24^{*}$ & 4.29 & 125.36 & 5.12 & 75.64 & Cm & $\begin{array}{l}\text { Quantitative } \\
\text { level of high } \\
\text { jump }\end{array}$ \\
\hline \hline
\end{tabular}

"T" value in the schedule is at $0.05=2.160$ significance level

* Statistically significant at level 0.05 
As table (2) shows, there are statistically significant differences at level 0.05 between the pre and the post tests of the (low level) experimental group in terms of the technical and quantitative performance in javelin throw in favor of the post test.

\section{Table (3)}

Indication of the differences between the pre and post tests for the (high level) experimental group in terms of the technical and quantitative performance in high jump $\mathrm{N}=10$

\begin{tabular}{l|c|c|c|c|c|l}
\hline \multirow{2}{*}{$\begin{array}{l}\text { T } \\
\text { value }\end{array}$} & \multicolumn{2}{|c|}{ Post test } & \multicolumn{2}{c|}{ Pre test } & \multicolumn{1}{c|}{$\begin{array}{c}\text { Unit of } \\
\text { Measurement }\end{array}$} & Variables \\
\cline { 2 - 7 } & dependent & independent & dependent & independent & Mark & $\begin{array}{l}\text { Level } \\
\text { technical } \\
\text { performance } \\
\text { in high jump }\end{array}$ \\
\hline $13.91^{*}$ & 0.49 & 7.00 & 0.53 & 1.20 & of \\
\hline $21.18^{*}$ & 5.75 & 130.00 & 5.11 & 76.00 & Cm & $\begin{array}{l}\text { Quantitative } \\
\text { level of high } \\
\text { jump }\end{array}$ \\
\hline \hline
\end{tabular}

"T" value is at $0.05=2.262$ significance level

* Statistically significant at level 0.05

As table (3) shows, there are statistically significant differences at level 0.05 between the pre and the post tests of the (high level) experimental group in terms of the technical and quantitative performance in high jump in favor of the post test.

The researcher attributes the improvement of the level of technical and quantitative performance in high jump among the individuals of the (low level - high level) experimental group to the use of hypermedia-supported individualized teaching by the means of the suggested educational program in which the researcher has respected the individual differences between the learners and their ability to learn. She has broken down the skill into small parts in light of its logical sequence in an organized and consecutive manner and linked them linearly in the form of photos, videos and shots from high jump international competitions. All this has helped the learners to learn rapidly thanks to the attractive educational atmosphere; given that computer is one of the most important devices that could help students to interact with each other and with the educational curriculum in a learning process that provides the learner with feedbacks, 
which results in increasing the quality and quantity of education. Also, the availability of various patterns of navigation in hypermedia software and the abundance of means of content presentation in a way that suits lower level learners helps in repeating the content several times in order to achieve the required level of mastery and to achieve the knowledge and information required from them in accordance with their own rhythm.

This result is consistent with the following studies: Sally Mohammed Abdullatif (2005), Mohammed Abdu Khedr (2010), Hany Ahmed Abdulaal (2011) on the importance of hypermedia- supported individualized learning (Keller plan) in the learning and mastery of motor skills in both individual and team sports.

Furthermore, this result is consistent with the results of the following studies: Hadeer Mustafa Mohammed (2004), Waleed Mustafa Haroon (2009), Mohammed Salah Ahmed (2012), Hussein Ahmed Hussein (2013), Shaimaaa Nafe' Awad (2014) on the importance of the use of hypermedia in the learning and mastery of high jumping skill.

Thus, the validity of the first hypothesis of the research has been established.

Second: Presentation and discussion of the second hypothesis of the research:

\section{Table (4)}

Indication of the differences between the pre and post tests of the (low level) control group in terms of the technical and quantitative performance in high jump $\mathrm{N}=13$

\begin{tabular}{c|c|c|c|c|c|c}
\hline \hline $\begin{array}{c}\mathbf{T} \\
\text { value }\end{array}$ & \multicolumn{2}{|c|}{ Post test } & \multicolumn{2}{c|}{ Pre test } & $\begin{array}{c}\text { Unit of } \\
\text { Measurement }\end{array}$ & Variables \\
\cline { 2 - 7 } & dependent & Independent & Depended & Independent & & $\begin{array}{l}\text { Level of } \\
\text { technical } \\
\text { performance } \\
\text { in high } \\
\text { jump }\end{array}$ \\
\hline \hline & 0.93 & 5.00 & 0.59 & 0.83 & Mark \\
\hline $15.67^{*}$ & 4.17 & 113.85 & 5.03 & 75.32 & $\mathrm{Cm}$ & $\begin{array}{l}\text { Quantitative } \\
\text { level of high } \\
\text { jump }\end{array}$ \\
\hline \hline
\end{tabular}

T-value is at $0.05=2.179$ significance level

* Statistically significant at level 0.05

As table (4) shows, there are differences at level 0.05 statistically significant between the pre and the post Assiut Journal For Sport Science Arts 
tests of the (low level) control group in terms of the technical and quantitative performance in high jump in favor of the post test.

\section{Table (5)}

Indication of the differences between the pre and post tests of the (high level) experimental group in terms of the technical and quantitative performance in high jump $\mathrm{N}=11$

\begin{tabular}{c|c|c|c|c|c|c}
\hline \hline $\begin{array}{c}\text { T } \\
\text { value }\end{array}$ & \multicolumn{2}{|c|}{ Post test } & \multicolumn{2}{c|}{ Pre test } & $\begin{array}{c}\text { Unit of } \\
\text { Measurement }\end{array}$ & Variables \\
\hline \hline $12.41^{*}$ & 0.72 & 5.91 & 0.55 & 1.09 & Mark & $\begin{array}{l}\text { Level of } \\
\text { technical } \\
\text { performance } \\
\text { in high jump }\end{array}$ \\
\hline $17.53^{*}$ & 5.26 & 120.00 & 5.19 & 75.81 & Cm & $\begin{array}{l}\text { Quantitative } \\
\text { level of high } \\
\text { jump }\end{array}$ \\
\hline \hline
\end{tabular}

"T" value is at $0.05=2.228$ significance level

* Statistically significant at level 0.05

As table (5) shows, there are statistically significant differences at level 0.05 between the pre and the post tests of the (high level) control group at the level of technical and quantitative performance in high jump in favor of the post test.

The researcher attributes the improvement of the technical and quantitative performance in high jump among the individuals of the (low level high level) control group to the teacher's focus on exposing the skill under consideration practically through a practical model and providing a simplified verbal explanation of the skill so that the learner could has a clear visualization of the stages of the technical performance of high jumping skill. Also, the teacher provides instructions and advice when necessary so that the learner could correct his technical mistakes immediately after their emergence.

This result is consistent with Martin \& Lumsden (1987) and Ellen Wadee' (2000) who have idicated that when the teacher provides the learner with a clear idea about the performance in a correct scientific manner, this makes the learner's performance more effective and that one of the best styles of skill learning is the style in which the teacher exposes the skill to the learner and provides a correct performance model of it in order to enable the learner to 
discover the movements of his own body.

Thus, the validity of the second hypothesis has been established

Third: Presentation and discussion of the results of the third hypothesis of the research:

\section{Table (6)}

Indication of the differences between the pre and post tests of the (low level) experimental and control groups in terms of the technical and quantitative performance in high jump

\begin{tabular}{l|c|c|c|c|c|c}
\hline \hline \multirow{2}{*}{$\begin{array}{l}\text { T } \\
\text { value }\end{array}$} & $\begin{array}{c}\text { The experimental group } \\
\text { N=14 }\end{array}$ & \multicolumn{2}{|c|}{$\begin{array}{c}\text { The control group } \\
\text { N=13 }\end{array}$} & $\begin{array}{c}\text { Unit of } \\
\text { Measurement }\end{array}$ & Variables \\
\cline { 2 - 5 } & Dependent & Independent & Dependent & Independent & \\
\hline \hline $6.48^{*}$ & 0.63 & 5.00 & 0.51 & 6.48 & Mark & $\begin{array}{l}\text { Level of } \\
\text { technical } \\
\text { performance } \\
\text { in high } \\
\text { jump }\end{array}$ \\
\hline $4.69^{*}$ & 4.17 & 113.85 & 4.29 & 121.79 & $\mathrm{Cm}$ & $\begin{array}{l}\text { Quantitative } \\
\text { level of high } \\
\text { jump }\end{array}$ \\
\hline \hline
\end{tabular}

"T" value in the schedule is at $0.05=2.060$ significance level

* Statistically significant at level 0.05

As table (6) shows, there control groups in terms of the are statistically significant differences at level 0.05 between the post tests of the (low level) experimental and technical and quantitative performance in high jump in favor of the post test.

Table (7)

Indication of the differences between the pre and post tests for the (high level) experimental and control groups in terms of the technical and quantitative performance in high jump

\begin{tabular}{|c|c|c|c|c|c|c|}
\hline \multirow[t]{2}{*}{$\begin{array}{c}\mathbf{T} \\
\text { value }\end{array}$} & \multicolumn{2}{|c|}{$\begin{array}{l}\text { The experimental group } \\
\mathrm{N}=11\end{array}$} & \multicolumn{2}{|c|}{$\begin{array}{c}\text { The control group } \\
\mathrm{N}=10\end{array}$} & \multirow[t]{2}{*}{$\begin{array}{c}\text { Unit of } \\
\text { Measurement }\end{array}$} & \multirow[t]{2}{*}{ Variables } \\
\hline & dependent & Independent & dependent & Independent & & \\
\hline $3.82 *$ & 0.72 & 5.91 & 0.49 & 7.00 & Mark & $\begin{array}{l}\text { Level of } \\
\text { technical } \\
\text { performance in } \\
\text { high jump }\end{array}$ \\
\hline $5.43 *$ & 5.26 & 120.00 & 5.75 & 130.00 & $\mathrm{Cm}$ & $\begin{array}{l}\text { Quantitative } \\
\text { level of high } \\
\text { jump }\end{array}$ \\
\hline
\end{tabular}

"T" value is at $0.05=2.093$ significance level

* Statistically significant at level 0.05 
As table (7) shows, there are statistically significant differences at level 0.05 between the post tests of the (high level) experimental and control groups in terms of the technical and quantitative performance in high jump in favor of the experimental group.

The researcher attributes the superiority of the experimental group over the (low level - high level) control group in terms of technical and quantitative performance in high jump to the use of hypermedia-supported individualized teaching in the suggested educational program to which the experimental group was introduced, and this because hypermedia include (animations - fixed and sequential images - written texts - slow motion video display - colors - music) all this led to the learning and mastery of the technical stages of high jumping skill, and made the learning process easy and interesting, which had a great effect on the good learning of the skill. While the command teaching style to which the control group was introduced lacks all this features of the hypermedia, as it depends on verbal explanations style and the only performance of the practical model. This result is consistent with Wafeeka Mustafa Hassan (2007) who has pointed out that individualized learning contributes to the improvement of the educational process by adjusting the time pattern of each learner in accordance with his personal abilities, so the learner passes from an educational step to the next one in accordance with his own abilities and potentialities.

This result is also consistent with the following studies: Sally Mohammed Abdullatif (2005), Mohammed Abdu Khedr (2010), and Hany Ahmed Abdula'l (2011) on the efficiency of the use of hypermedia-supported individualized learning in the learning of motor skills compared to command teaching style. 
Table (8)

Rate of improvement of the post test compared to that of the pre test for the (low level) experimental and control groups in terms of technical and quantitative performance in high jump

\begin{tabular}{c|c|c|c|c|c|c|}
\hline \hline \multicolumn{2}{c|}{ The control group N=13 } & \multicolumn{3}{|c|}{ The experimental group N=14 } & Variables \\
\hline $\begin{array}{c}\text { Rate of } \\
\text { improvement }\end{array}$ & $\begin{array}{c}\text { Post } \\
\text { test }\end{array}$ & $\begin{array}{c}\text { Pre } \\
\text { test }\end{array}$ & $\begin{array}{c}\text { Rate of } \\
\text { improvement }\end{array}$ & $\begin{array}{c}\text { Post } \\
\text { test }\end{array}$ & $\begin{array}{c}\text { Pre } \\
\text { test }\end{array}$ & \\
\hline \hline $502.41 \%$ & 5.00 & 0.83 & $548.00 \%$ & 6.48 & 1.00 & $\begin{array}{l}\text { Level of } \\
\text { technical of } \\
\text { performance } \\
\text { in high jump }\end{array}$ \\
\hline $51.16 \%$ & 113.85 & 75.32 & $61.01 \%$ & 121.79 & 75.64 & $\begin{array}{l}\text { Quantitative } \\
\text { level of high } \\
\text { jump }\end{array}$ \\
\hline \hline
\end{tabular}

As table (8) shows, the individuals of the experimental group has surpassed those of the (low level) control group in terms of the superiority of the

\section{Table (9)}

Rates of improvement in the post test compared to the pre test for the (high level) experimental and control groups in terms of technical and quantitative performance in high jump

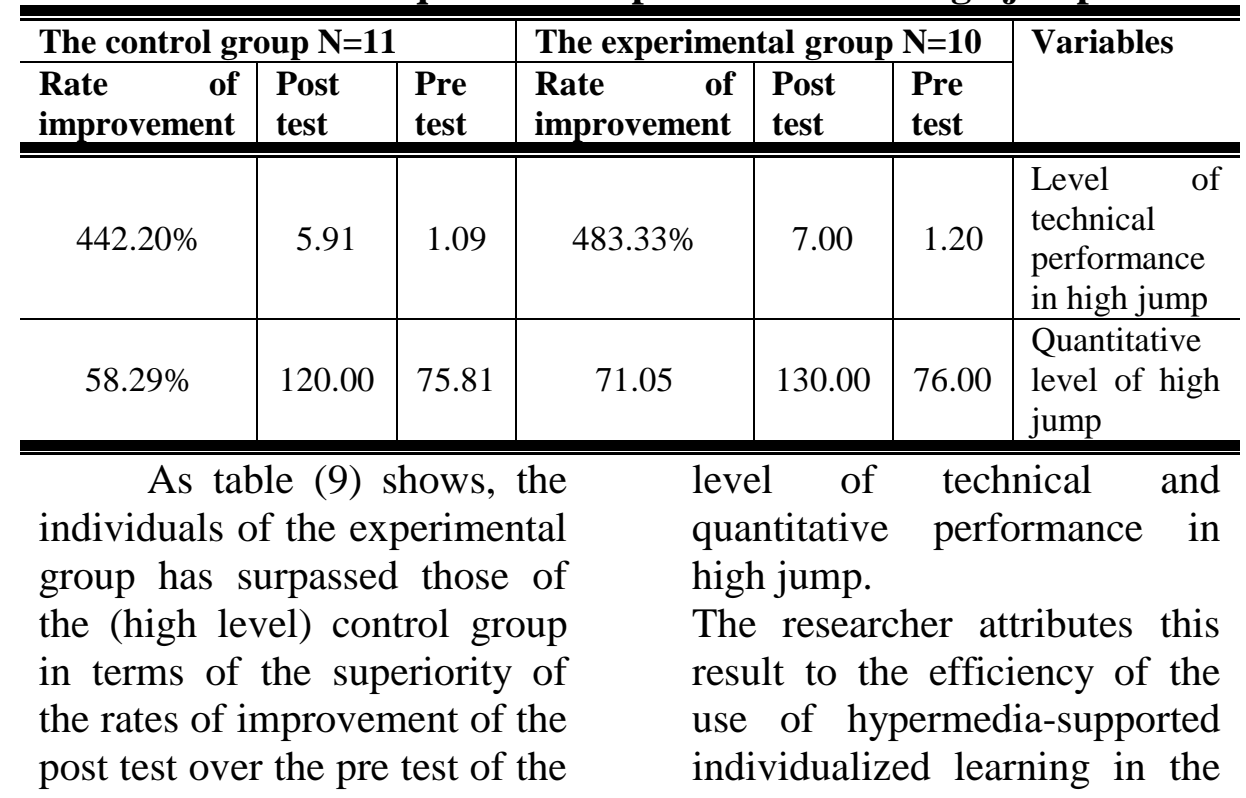

Assiut Journal For Sport Science Arts 
suggested educational program, the ability of hypermedia to draw the learner's attention to the suspense, the fact that it involves various senses (hearing - sight) and depends on increasing the learners' enthusiasm and motivation towards the implementation of a better performance.

Thus, the validity of the research's third hypothesis has been established

\section{Findings:}

- Hypermedia-supported

individualized education has a statistically significant and positive impact at level 0.05 on the level of technical and quantitative performance in high jump.

- $\quad$ Command teaching style (the traditional method) has a statistically significant and positive impact at level 0.05 on the level of technical and quantitative performance in high jump.

- The efficiency of hypermedia-supported individualized education surpasses that of the command teaching style in terms of the technical and quantitative performance in high jump.
- The individuals of the experimental group has surpassed those of the (low level - high level) control group in terms of the rates of improvement of the post test compared to the pre test of the level of technical and quantitative performance in high jump.

\section{Recommendations:}

- The necessity of using hypermedia-supported individualized education in learning and mastering high jumping skills for the secondyear undergraduate students at the Faculty of Physical Education at Zagazig.

- Carrying out an initial classification of the learners since the beginning and arranging them in groups of approximate level.

- The establishment of a special hypermedia laboratory in the department of track and field events at the Faculties of Physical Education.

- Encouraging the members of the teaching staff to use hypermedia-supported individualized learning in teaching the different aspects of the program of track and field events in order to avoid the inflexible traditional teaching method. 
- Conducting similar studies using individualized teaching plans and identifying its impact on the learning of the remaining different aspects of the curriculum of track and field events.

Bibliography:

First: Arabic references:

1- Abu El-Naga Ezz Eddin (2001): Physical Education Teacher, Dar El-Asdeka', ElMansoura.

2- El-Sayed Mohamed Khairy (1989): Intelligence Test (Instructions and Applications), Dar El-Nahda El-Arabia - Cairo.

3- Ellen Wadee' Faraj (2000): Experiences in Games for Adults and Children, Monsha'at El-Maaref, Alexandria.

4- Bastaweesy Ahmed Bastaweesy (1997): Track and Field Events, Education Tactics - Training, Dar El-Fikr Al-Araby, Cairo.

5- Hussein Ahmed Hussein (2015): the Impact of Hypermedia on the Learning of High Jumping by Means of Fosbury Method for Deaf and Hard of Hearing High School Students, Master Thesis, Faculty of Physical Education, South Valley University.
6- Hussein Kamal Baha' Eddin (2004): Teaching and the Future, Dar El-Ma'aref. Cairo.

7- Helmy El-Wakeel, Hussein El-Basheer (2012): Modern Trends in the Planning and Development of the First Cycle Program, $2^{\text {nd }}$ ed., Dar Al-Fikr Al-Araby, Cairo.

8- Sally Mohammed Abdullatif (2005): "Efficiency of a Hypermedia-Supported Suggested Educational Program based on Keller Plan (Individualized Learning) on the Learning of Some Hockey Skills for the Students of the Faculty of Education, Tanta University, PhD thesis, Faculty of Physical Education, Tanta University.

\section{9- Shaimaa Nafe' Awad} (2014): "Impact of a Suggested Educational Program for the Teaching of High jumping and its Relation to the Enhancement of Self Confidence for the Students of the Preparatory Cycle", Master Thesis, Faculty of Physical Education for Girls, Zagazig University.

10- Abdulhamid Sharaf (2000): the Educational Technology in Physical Education, El-Kitab Center for Publishing, Cairo 
11- Abdulazim Abdulsalam El-Fargany (2000): The Technology of Educational Situations, Dar El-Huda For Publishing and Distribution, El-Minya

12- Issam Eddin Abdukhalek (2002): Physical Training, Theories and Applications, Monsha'at El-Maaref, Alexandria.

13- Ali Mohamed Abdulmoneim (2005):

Educational Technology and Educational Means, Dar ElMaarefa El-Jamiya, Alexandria.

\section{4- Kamal Yusuf Eskandar} (2000): Introduction to the Educational Technology, $2^{\text {nd }}$ ed., El-Fallah Library, Kuwait.

15- Kamal Yusuf Eskandar, Ahmed Kamal El-Hossary, Sofy Zaky (2007): Educational Technology and Educational Multimedia, Nour for Computer and Printing, Alexandria.

16- Mohammed Hassan Allawy, Mohammed Nasr Eddin Radwan (2001): Motor Performance Tests, $5^{\text {th }}$ ed., Dar El-Fikr El-Araby, Cairo.

17- Mohammed Reda Baghdadi (2012): Educational and Teaching Technology, Dar El-Fikr El-Araby, Cairo.
18- Mohammed Sa'd Zaghloul, Makarem Helmy Abu Harga, Hany Abdumoneim (2001): The Educational Technology and its Styles in Physical Education, El-Kotob Center for Publishing, Cairo.

19- Mohammed Sobhy

Hassanein

(2001):

Measurement and Assessment in Physical Education, $2^{\text {nd }}$ part, $4^{\text {th }}$ ed., Dar El-Fikr El-Araby, Cairo

20- Mohammed Salah Ahmed (2012): the Design of a Systematic Athletic Unit Using Computer at the Level of Skill Performance and Knowledge Acquisition among the Students of the Intelligent School At Assiut, PhD Thesis, Faculty of Physical Education, Assiut University.

21- Mohammed Abdu Khedr (2010): the Efficiency of an Educational Program based on Keller Plan in the Learning of High Jumping Skill for the Students of the Preparatory Cycle", Master Thesis, Faculty of Physical Education for Boys, Zagazig University.

22- Mohammed Attia Khamees (2003): Educational Technology Outcomes, Dar ElKalima Library, Cairo. 
23- Mohammed Attia Khamees (2009): Instructional and Educational Technology, Dar El-Sahab for Printing and Distribution, Cairo,

24- Mustafa El-Sayeh (2004): The Technological Methodology and the Educational and Information Technology in Physical Education, Dar ElWafaa for Printing and Distribution, Alexandria.

25- Mustafa Abdulsamee Mohammed (1999): The Educational Technology Arabic Studies, El-Kitab Center for Publishing, Cairo.

\section{6- Mustafa Abdulsamee}

Mohammed, Mohammed

Lotfy, Saber Abdulmoneim

(2001): Communication and Educational Media, Basic Readings for the Student Teacher, El-Kitab Center for Publishing, Cairo.

\section{7- Mahdy Salem (2002):}

Educational

Technintelligenceues and

Means, Dar El-Fikr El-Araby, Cairo.

\section{8- Hany Ahmed Abdulaal}

(2011): the Efficiency of Hypermedia-Supported

Individualized Learning on the Level of the Performance of
Basketball Skills for Deaf and Dumb Students", Physical Sciences and Arts Magazine, Vol. (38), Faculty of Physical Education for Girls, Helwan University.

29- Hadeer Mustafa Mohammed (2004): the Efficiency of Comprehensive Educational Multimedia in Teaching the Skills Aspect of High Jump Event for the Students of the Faculty of Physical Education, Females at Alexandria", Master Thesis, Faculty of Physical Education for Girls, Alexandria University.

30- Wafeeka Mustafa Salem (2001): Educational and Teaching Technology in Physical Education, Monshaat El-Maaref, Alexandria.

31- Wafeeka Mustafa Salem (2007): Educational and Teaching Technology in Physical Education, $2^{\text {nd }}$ ed., Monshaat El-Maaref, Alexandria.

32- Waleed Mustafa Haroon (2009): the Impact of a Hypermedia Video-based Suggested Program on the 
Learning of High Jumping for Beginners", Master Thesis, Faculty of Physical Education, El-Minya University.

Second: Foreign References: 33- Emck,J., \& Ferguson, H., (2005): Acomputer - Managed Kelle Plan (Electricity and Magnetum)Iop Electronic, Journal Plyicosics Education, Tech Univ., of Einrdhoven,Netherland,Http:// www.iopolg/fy/abstract/10021. 34- Gold,R., (1998): Microcomputer applications in health education, Dubuque, IA William C. Brown publishers. 35- Kevien Oliver (2000): Personalize Ed System of Instruction, www.keo.com. 36- Martin \& Lumsden (1987): Coaching an Effective Behavioral Approach, college publishing, Toronto.

37- Najar Lawrence (2005): Multimedia Information and Learning, Journal of Educational Multimedia and Hypermedia, Http:// multimedia_and_learning_html 